\title{
Timber identification of Autranella, Baillonella and Tieghemella in the taxonomically challenging Sapotaceae family
}

\author{
V. Deklerck ${ }^{1,2^{*}+}$ D, E. Price ${ }^{3,4+}$, S. Vanden Abeele ${ }^{5}$, K. Lievens $^{1}$, E. Espinoza ${ }^{4}$ and H. Beeckman ${ }^{1}$
}

\begin{abstract}
Background: To enforce timber import laws and perform timber species identification, the identity of the botanical species must be well-defined. Since the Sapotaceae family is known as a taxonomically challenging family, we focus in this study on the four most valuable Sapotaceae timber species from tropical Africa: Autranella congolensis (De Wild.) A.Chev., Baillonella toxisperma Pierre, Tieghemella africana Pierre and Tieghemella heckelii (A.Chev.) Pierre ex Dubard. The wood anatomical characteristic fiber lumen fraction and Direct Analysis in Real Time-Time of Flight Mass Spectrometry (DART-TOFMS) were used to differentiate the four species and to make inferences on species delineation and taxonomic identity.

Results: We observed differences in the fiber lumen fraction measurements and discerned two groups: (1) A. congolensis and B. toxisperma, and (2) T. africana and T. heckelii. In addition, all Mann-Whitney U comparisons and differences in distributions (Kolmogorov-Smirnov) for the fiber lumen fraction measurements were significant between all species. When permutating the data between species within those two groups, significant differences were still found between the species within those groups. This could indicate that the fiber lumen fraction is not diagnostic to discern the species. DART-TOFMS analysis showed that A. congolensis and B. toxisperma have distinct chemotypes, while $T$. heckelii and T. africana have remarkably similar chemotypes.

Conclusions: Based on our observations of similar chemotype and weakly differentiated fiber lumen ratio, we support an alternative taxonomic hypothesis that considers Tieghemella monotypic, because of the strong resemblance between T. heckelii and T. africana. Larger sample sizes and further research is required to develop methodology for the identification of these species. A taxonomic study utilizing molecular genetics would be beneficial to assess the status of the genus and the species limits. This could have implications towards their potential inclusion on CITES appendices if there is ever need for them to be listed. If Tieghemella africana and T. heckelii remain two distinct species, they should both be listed. Screening agents should be aware that the morphological and chemical differences between T. africana and T. heckelii are minimal.
\end{abstract}

Keywords: Sapotaceae, DART-TOFMS, Wood anatomy, Timber identification, Taxonomic identity

*Correspondence: victor.deklerck@gmail.com

${ }^{\dagger} \mathrm{V}$. Deklerck and E. Price contributed equally to this work as first authors

${ }^{1}$ Service of Wood Biology, Royal Museum for Central Africa (RMCA), Leuvensesteensweg 13, 3080 Tervuren, Belgium

Full list of author information is available at the end of the article

\section{Introduction}

Illegal logging and timber forensics

It is estimated that 30 to $90 \%$ of timber from the tropics is illegally sourced [1-6]. In addition to ecological damage, there are substantial economic and social problems associated with timber poaching [4]. These issues have sparked an increased demand for timber identification

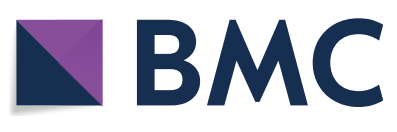

(c) The Author(s) 2021. This article is licensed under a Creative Commons Attribution 4.0 International License, which permits use, sharing, adaptation, distribution and reproduction in any medium or format, as long as you give appropriate credit to the original author(s) and the source, provide a link to the Creative Commons licence, and indicate if changes were made. The images or other third party material in this article are included in the article's Creative Commons licence, unless indicated otherwise in a credit line to the material. If material is not included in the article's Creative Commons licence and your intended use is not permitted by statutory regulation or exceeds the permitted use, you will need to obtain permission directly from the copyright holder. To view a copy of this licence, visit http://creativeco mmons.org/licenses/by/4.0/. The Creative Commons Public Domain Dedication waiver (http://creativecommons.org/publicdomain/ zero/1.0/) applies to the data made available in this article, unless otherwise stated in a credit line to the data. 
and timber traceability techniques, with current frontrunners being wood anatomy, both traditional and with machine vision [7-9], Direct Analysis in Real Time Timeof-Flight Mass Spectrometry (DART-TOFMS) [10-12], genetic analysis [13] and stable isotope ratio analysis [6, 14].

Wood anatomy, DART-TOFMS and genetic analysis are currently the most employed methods to determine the species identity of timber. However, timber import laws and adjoining timber species identification can only be followed if the identity of the botanical species is well defined. Until three decades ago, taxonomists mainly used morphological traits to describe and delineate species. However, species can show high levels of intraspecific morphological variation, which complicates accurate species delineation and occasionally results in the erroneous splitting of species. Conversely, differentiation and speciation are not always accompanied by morphological change, as demonstrated by the abundance of cryptic species [15-17], where two or more distinct genetic lineages are classified under the same taxonomic unit because they are seemingly indistinguishable from a morphological point of view [15]. For this reason, it is important to include molecular data when new species are described and named. Even when DNA-based methods are incorporated, genetic divergence can remain undetected resulting in wrongly delineated species. Reasons for this can include homoplasy (a shared character that did not arise from a common ancestor) and evolutionary processes such as hybridization (production of viable offspring by parents from different varieties or species), chloroplast capture (introgression of a chloroplast genome from one species into another), reticulate evolution (or network evolution, where a group of organisms originates through the partial merging of ancestor lineages) or incomplete lineage sorting (common ancestry of gene copies at a single locus extends deeper than previous speciation events) $[16,18-20]$.

\section{Sapotaceae}

The Sapotaceae family is known for its highly homoplasious morphological characters and the lack of unambiguous synapomorphies for subfamilies and tribes [21], leading to the dynamic nature of the Sapotaceae taxonomy and the many taxon synonyms [22]. Here, we will focus on the four most important Sapotaceae timber species from tropical Africa: Autranella congolensis (De Wild.) A.Chev., Baillonella toxisperma Pierre, Tieghemella africana Pierre and Tieghemella heckelii (A.Chev.) Pierre ex Dubard [23]. All four species represent the largest trees in their respective forested regions, reaching heights of $50 \mathrm{~m}$ or more and diameters of sometimes more than $2 \mathrm{~m}$.
Tieghemella africana is well-known to the international timber trade as Douka [24]. This trade name can occasionally cover timber from $B$. toxisperma and is often considered as the same trade category as wood from $T$. heckelii. However, T. heckelii is traded under the generic trade name (or pilot name) Makoré, which can include timber from T. africana and B. toxisperma. Tieghemella africana is typically found in the evergreen rainforests from Cameroon to Cabinda (Angola) in the west, and eastward to the Republic of the Congo and Democratic Republic of the Congo (DRC) [25]. The highest species densities are reported in Equatorial Guinea, western Gabon and in the Republic of the Congo, north of Kouilou. In other regions it can be mixed with $T$. heckelii and B. toxisperma. Heartwood of T. africana is very similar to $T$. heckelii but tends to be more intensely stained with a more distinct vein pattern (for an image of the heartwood of all species, please see Additional file 1: Figure S1). In provenances from the Republic of the Congo, the wood has been noted to darken to a red violet colour. In addition, $T$. africana tends to be slightly harder and heavier than T. heckelii. The main distribution area for $T$. heckelii covers eastern Liberia, Côte d'Ivoire and Ghana, but the species also occurs in lower densities in Nigeria [26]. As such, the range of T. heckelii overlaps with other morphologically similar Sapotaceae species, creating a challenge for field identification. Baillonella toxisperma and A. congolensis occur in low densities in the rainforest of southern Nigeria, Cameroon, Equatorial Guinea, Gabon, Cabinda (Angola), Republic of the Congo and the Democratic Republic of the Congo (DRC) [27, 28]. Baillonella toxisperma (Moabi), can look very similar to $T$. heckelii, but the distinction is clearer than for T. africana from Ghana or the Ivory Coast. Baillonella toxisperma is also found mixed with shipments of T. africana and $T$. heckelii. Autranella congolensis is reported to be falsely sold as B. toxisperma, but Autranella congolensis wood is harder and darker with a violet colour. Standing trees of $B$. toxisperma and $A$. congolensis are quite similar to each other, with one primary difference being $B$. toxisperma exhibits a distinctively flatter crown [24].

\section{Taxonomic history}

Although the four Sapotaceae species in this study are currently assigned to three distinct genera, all four species were previously included in the genus Mimusops [22]. Autranella congolensis seems to be related to the latter, but it differs in having stipules, a longer corolla tube and larger fruits [27] and was thus reinstated as a distinct (monotypic) genus. The genus Baillonella was first described by Pierre based on a seed collected in Gabon [29]. Engler then included the genus as a section in Mimusops, but the group was later reinstated as 
a separate genus because of the thin seed coat and particular leaf veins that distinguish it from the Mimusops [30]. While multiple Baillonella species were described in the 1900s, B. toxisperma is currently the only recognized species. The genus Tieghemella was first described by Pierre [29], but was later subsequently added to the genera Dumoria, Mimusops and Baillonella, after which Tieghemella was reinstated as a distinct genus. Currently, T. africana and T. heckelii are the only two species recognized in the genus. However, a taxonomic study is needed to assess the status of the genus and the species limits, since they may be conspecific $[25,26]$ as suggested by the chemical analysis as well (see further).

\section{Study objectives}

As indicated, these Sapotaceae species all have similar dense and reddish-brown wood. Because of this similarity, the wood is used for similar purposes and often traded together under the same commercial name. As such it is important (1) to be able to identify these species within the timber trade and (2) to be certain that these are four different species. In this study, we will:

(1) Assess the robustness of the one wood anatomical characteristic that is claimed to allow for the differentiation of these four Sapotaceae species: the fiber lumen fraction (referred to as the coefficient de souplesse by [31, 32]).

(2) Assess the efficacy of using chemical fingerprints via DART-TOFMS for species differentiation.

(3) Draw inferences from the conclusions of (1) and (2) towards the species delineation and the taxonomic identity of these four Sapotaceae species.

\section{Materials and methods \\ Sampling}

A total of 65 wood specimens were used, 62 collected from the Tervuren Wood Collection (Royal Museum for Central Africa, Tervuren, Belgium) and three from the World Forest ID project [33] (see Additional file 2: Table S1). Some of these wood specimens were used for wood anatomical analysis $(n=17)$ and all except one were used to obtain chemical fingerprints via DARTTOFMS $(n=64)$. Two samples from the Tervuren Wood Collection have a corresponding herbarium voucher at Meise Botanic Garden (BR) in Belgium (Additional file 2: Table S1).

\section{Wood anatomical analysis}

The anatomical differences between species determined via the IAWA list of microscopic features [34] on InsideWood [35] were compared to the anatomical slices obtained in this study. Anatomical cross-sections (transverse) of 16 wood specimens (Table 1 and Additional file 2: Table S1) were digitized at $20 \times$ magnification using Stream Image Analysis Software (StreamMotion, Olympus, Tokyo, Japan) with a scanning stage (Märzhäuser Wetzlar, Wetzlar, Germany) and a UC30 camera (Olympus, Tokyo, Japan) mounted on a light microscope (BX60, Olympus, Tokyo, Japan). For each image, fibers were used to determine the fiber lumen fraction:

$$
\begin{aligned}
\text { Fiber lumen fraction }(\%)= & (\text { diameter lumen/diameter fiber }) \\
& * 100
\end{aligned}
$$

Images were aligned in transverse direction and the fiber lumen fraction was determined in two perpendicular directions on the fiber ( 4 measurements per fiber $=2$ fiber lumen fractions, Fig. 1). The average of those two measurements was taken as the fiber lumen fraction of that fiber.

Notched boxplots were created using the ggplot2 package [36] in RStudio (Rstudio Team, 2016). Boxplots show the total distribution of measurements and notched boxplots offer a quick visual check whether a statistical difference in median can be expected. Normality of the data was checked using the Shapiro-Wilk test [37] and the non-parametric independent 2-group Mann-Whitney $\mathrm{U}$ test was used to determine whether the fiber lumen fractions come from the same population [38]. In addition, the Kolmogorov-Smirnov test was used as an extra check to determine whether the distribution of fiber lumen fractions were distinct for each species. Where the Mann-Whitney U test works with the rank of values,

Table 1 The number of fiber lumen fraction measurements per species, their mean and standard deviation and the samples used from the Tervuren Wood Collection (Tw)

\begin{tabular}{lllll}
\hline Species & $\mathbf{n}$ & Average (\%) & Std (\%) & Samples used from Tw collection \\
\hline Autranella congolensis & 210 & 38.67 & 9.04 & $633,923,1175,1578$ \\
Baillonella toxisperma & 251 & 44.49 & 6.56 & $10,754,27,547,30,909,44,837,50,839$ \\
Tieghemella africana & 218 & 64.23 & 9.60 & $10,761,18,800,22,610,26,512$ \\
Tieghemella heckelii & 281 & 70.34 & 9.08 & $18,005,21,571,26,510,31,670$ \\
\hline
\end{tabular}




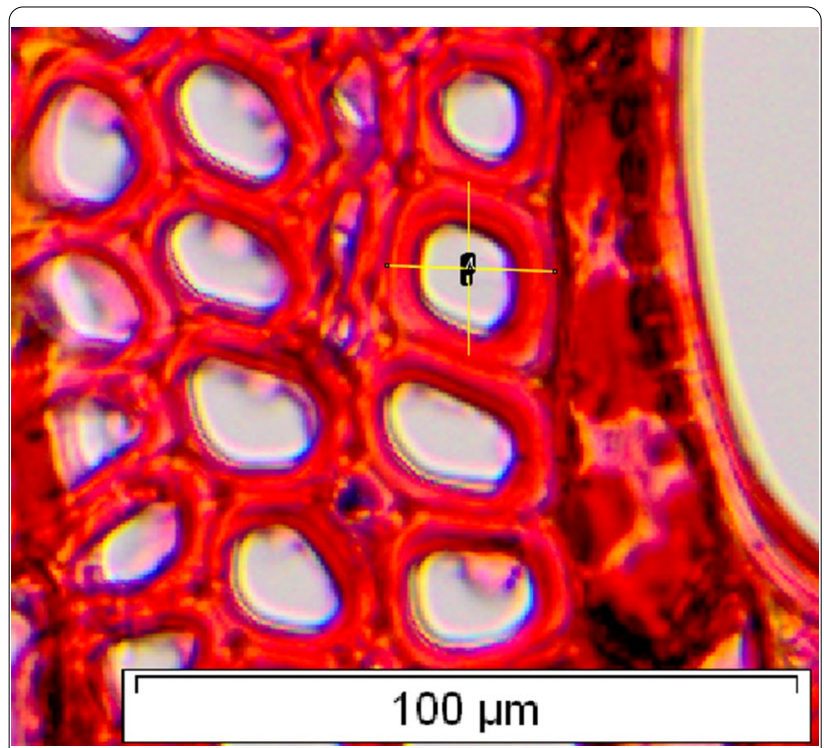

Fig. 1 Example of the fiber lumen fraction measurements. The fiber lumen fraction of the fiber is taken as the average of two measurements in perpendicular directions. Sample: Tw18005, Tieghemella heckelii

the Kolmogorov-Smirnov test compares the cumulative distribution of the datasets. Finally, 35 permutations were run in combination with the non-parametric independent 2-group Mann-Whitney $U$ test to determine whether the comparisons indicate real differences in fiber lumen fraction between the two species groups (A. congolensis/B. toxisperma and T. africana/T. heckelii). For the group A. congolensis/B. toxisperma, four Tw samples belonging to these two species were randomly picked and placed under $A$. congolensis, the same was done for $B$. toxisperma. This was repeated for each of the 35 permutations. Per permutation run, one sample was not used, as there are nine samples between those species (see Table 1). This was to keep the dataset balanced. The same was done for the species group $T$. africana/T. heckelii with four samples randomly picked each permutation run per species.

\section{DART-TOFMS}

A training set was created consisting of heartwood slivers taken from $A$. congolensis individuals $(n=21), B$. toxisperma $(n=21), T$. africana $(n=4)$, and T. heckelii $(n=6)$ (Additional file 2: Table S1). Due to limitations regarding availability of verified specimens, two spectra were collected from each Tieghemella sample. Spectra were collected with a TOF Mass Spectrometer (AccuTOF, JEOL, USA, INC., Peabody, MA. USA) equipped with a DART ion source (DART-SVP, IonSense Inc., Saugus, MA. USA). Each spectrum was acquired in the range of $50 \mathrm{~m} / z$ to $1000 \mathrm{~m} / z$ by holding the sample with forceps in a protonated helium gas stream heated to $350{ }^{\circ} \mathrm{C}$ for approximately $7 \mathrm{~s}$. Spectra were calibrated using poly(ethylene glycol) 600 (Ultra Scientific, Kingstown, RI, USA), then averaged and background subtracted with msAxel (version 1.0.5.2, JEOL Ltd.). Mass spectra were centroided and exported as text files for analysis using Mass Mountaineer software (RBC Software, Peabody, MA, USA). Detailed instrument parameters can be found in [11].

Using Mass Mountaineer, samples were initially grouped into four separate classes: A. congolensis, B. toxisperma, T. africana, and T. heckelii. Ions were selected with a $5 \%$ threshold and a mass tolerance of $5 \mathrm{mmu}$. The total number of ions selected for Principal Component Analysis (PCA) was $n=907$. For the Discriminant Analysis of Principal Components (DAPC) model, the total number of ions was reduced by applying Analysis of Variance (ANOVA), wherein each statistically significant $\mathrm{m} / \mathrm{z}$ value for discrimination between class means $(p \leq 0.05)$ was retained for a total of 495 ions (Mass Mountaineer Guide, Version 6.0.0.0). The PCA with the four species as separate classes was constructed using 28 PCs encompassing $90 \%$ of variance (Additional file 3: Figure S2). Since the Tieghemella species showed a grouping trend in the PCA (Fig. 4), it was decided to group both species into a single class in the subsequent classification analysis. Between class variation was calculated by applying DAPC and the performance of the model was calculated using Leave-One-Out-Cross-Validation (LOOCV) [11, 39, 40]. An additional set of spectra not included in the training set was used as a test set for the model. These consisted of $A$. congolensis $(n=2), B$. toxisperma $(n=3)$, T. africana $(n=1)$, and T. heckelii $(n=2)$. No spectra from the training set, including replicates, were used for testing the model. An additional DAPC model was generated to evaluate the Tieghemella species alone.

\section{Results}

\section{Wood anatomical analysis}

Autranella congolensis had the lowest mean fiber lumen fraction compared to the other species (Table 1), but the range of values showed some overlap with $B$. toxisperma due to the high standard deviation. The two Tieghemella species had a noticeably higher mean fiber lumen fraction, with $T$. heckelii having the highest value. The notched boxplots showed two groups based on the distribution of the fiber lumen fraction measurements: A. congolensis/B. toxisperma and T. africana/T. heckelii. (Fig. 2). Furthermore, the Mann-Whitney U test rejected the null hypothesis that the fiber lumen fractions for the species came from the same population and the KS test showed a high significance $(p<0.001)$, indicating the 


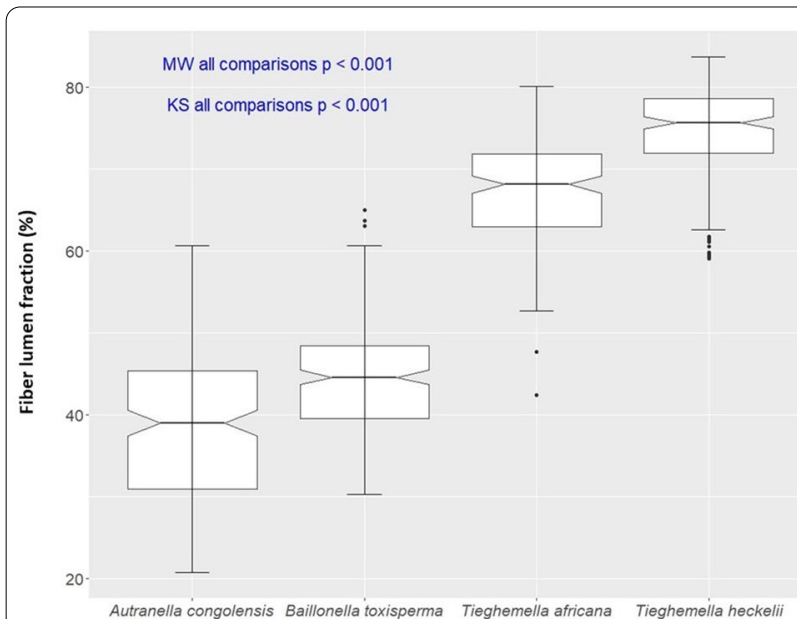

Fig. 2 Notched boxplots of the fiber lumen fraction for each of the species. The independent 2-group Mann-Whitney $U$ test and Kolmogorov-Smirnov showed significant differences between all species

difference in distribution. However, when we conducted independent 2 group Mann-Whitney U tests, differences were significant for a proportion of permutations $(74 \%$ significant comparing $A$. congolensis and B. toxisperma; $80 \%$ comparing T. africana and T. heckelii). This indicates overlap in fiber lumen fraction between individuals of different species.

\section{DART-TOFMS}

The heatmap of the mass spectra shows that the ion pattern from $90-215 \mathrm{~m} / z$ was present in all four species (Fig. 3). Higher relative abundance at $409.163 \mathrm{~m} / z$ was noted for $A$. congolensis. Higher relative abundance of ions at $434.316,440.326$ and $452.310 \mathrm{~m} / z$ appeared to be indicative of the Tieghemella species. Baillonella toxisperma showed an ion at approximately $84.081 \mathrm{~m} / z$, which was not found or was observed at lower relative abundance in the other species, and also showed a higher relative abundance of the ion at $130.087 \mathrm{~m} / z$.

The PCA scatterplot (Fig. 4) showed distinctive grouping for A. congolensis and B. toxisperma, while T. africana and $T$. heckelii group together. There appeared to be three outlier spectra, one from $A$. congolensis and two from $B$. toxisperma. The outlier of $A$. congolensis (Tw4300), and one from B. toxisperma (Tw2101), did not group with any other species class, while the other outlier from the $B$. toxisperma class (Tw1675) grouped with A. congolensis. These outliers may have been due to misidentifications at the field collection stage or human error. Regardless,

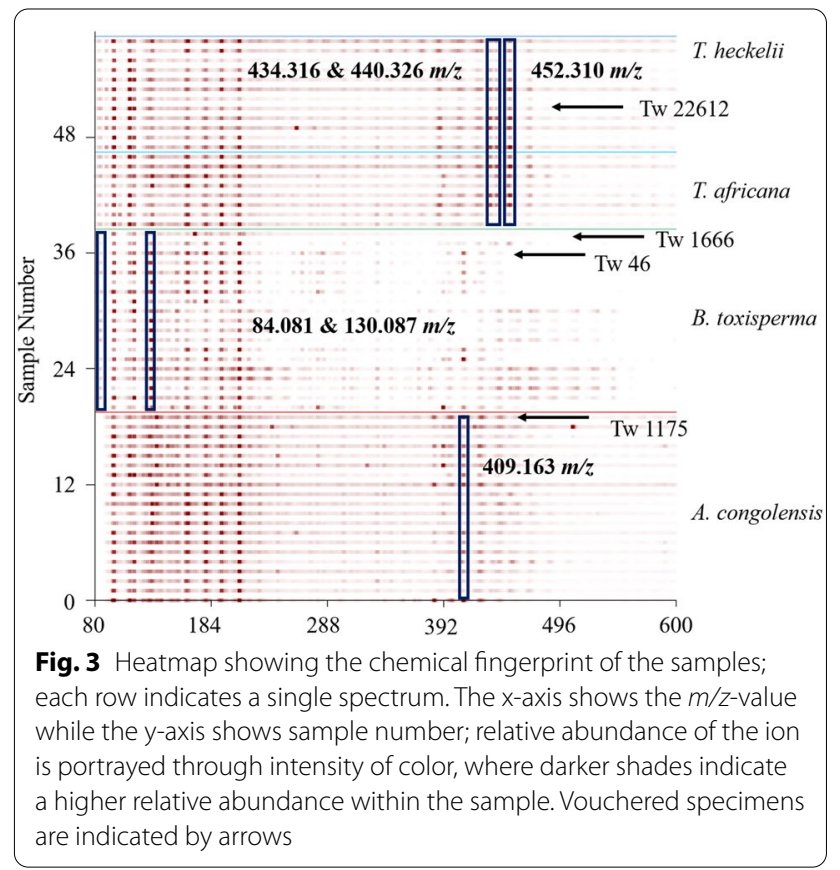

they were removed from the PCA model and subsequent analysis, bringing the total number of ions to $n=792$.

The DAPC model without the outliers and with T. africana and T. heckelii spectra in a single class, Tieghemella spp., showed distinctive grouping between the three classes (Fig. 5). The calculated LOOCV value for the DAPC model was $96.61 \%$, indicating that two spectra $(B$. toxisperma Tw1666 and T. heckelii Tw22612) were misclassified. All test samples $(n=8)$ were correctly assigned (Table 2).

Analysis of the Tieghemella species indicated that the species' chemotypes are remarkably similar (Fig. 6). Some variation in ion intensity can be seen between the species. However, this variation also changes from sample to sample (Fig. 3) but the overall ion pattern (Fig. 6) remains consistent.

An additional PCA scatterplot (Additional file 4: Figure $S$ ) and DAPC model (Figure not shown) were created using replicates from all T. heckelii $(n=16)$ and $T$. africana $(n=10)$ samples. All observed ions $(n=352)$ were used and based on the PCA plot, the species did not show separating trends. The ions underwent ANOVA, leaving a total of 29 ions for DAPC analysis. The LOOCV value of the DAPC model was $84.62 \%$; all T. heckelii samples were correctly assigned to their class, while only 6 of the 10 T. africana samples were correctly assigned. 


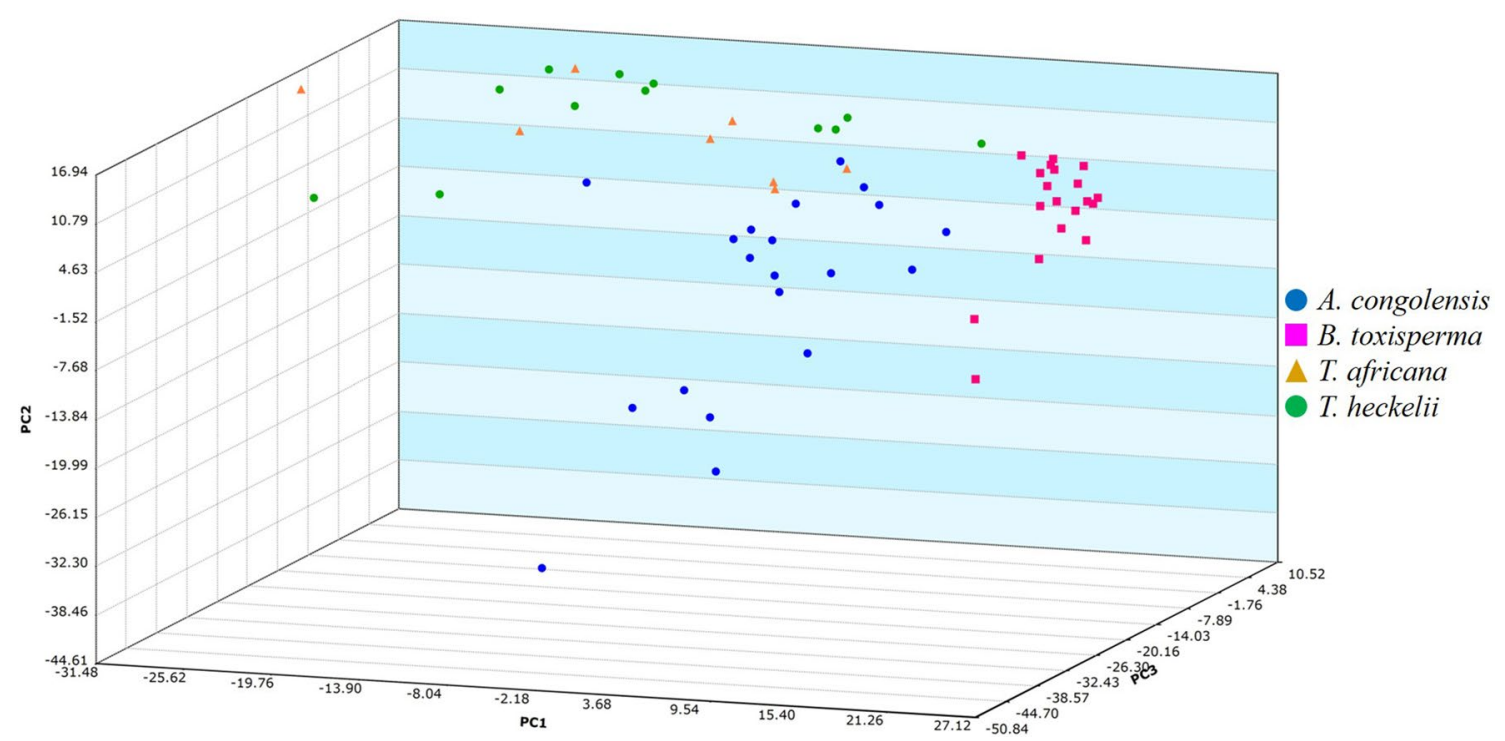

Fig. 4 Principal Component Analysis of mass spectra from the four Sapotaceae species. All species exhibited separate clustering trends except for the Tieghemella spp.

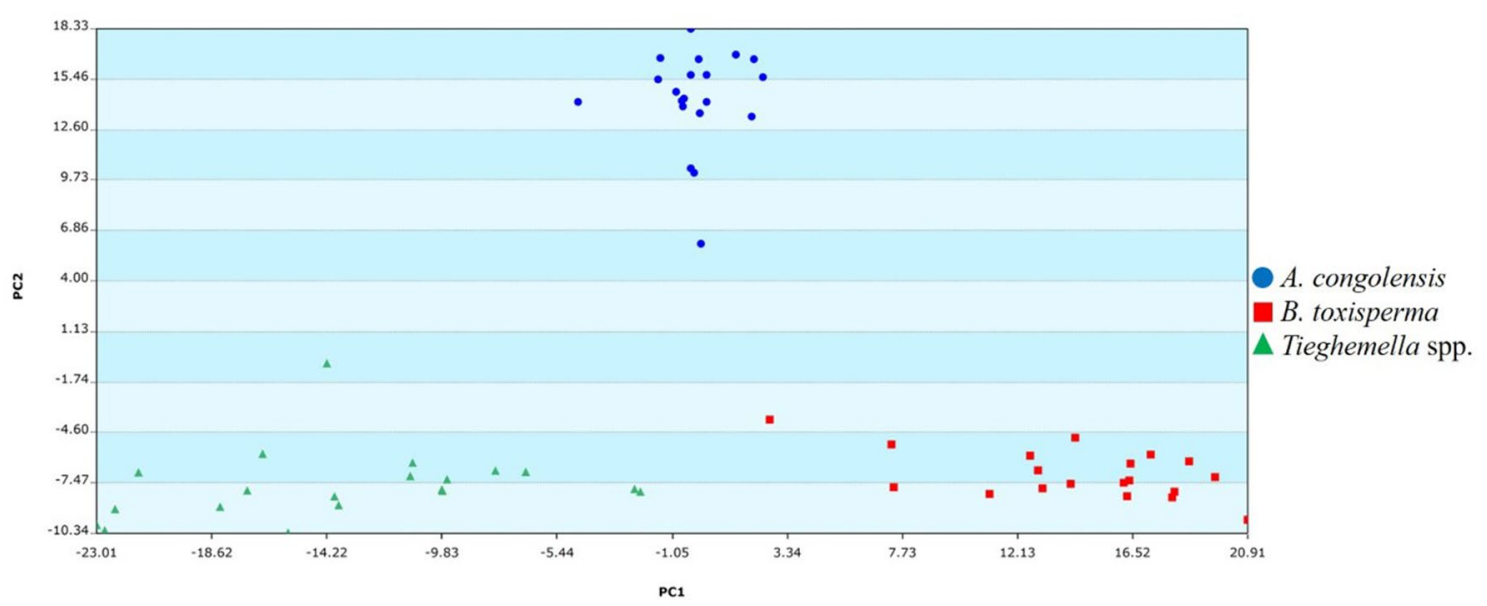

Fig. 5 Scatterplot of the DAPC model showing the variation between A. congolensis, B. toxisperma and Tieghemella spp. (LOOCV=96.61\%)

\section{Discussion}

\section{Wood anatomical analysis}

The wood of A. congolensis, B. toxisperma, T. africana and $T$. heckelii is used for similar purposes and often traded together under the same commercial name. In addition, the taxonomic history of the Sapotaceae has not been unequivocal. As such it is required for law enforcement (1) to be able to identify these species within the timber trade and (2) to be certain that these are four different species. When comparing the four species in terms of the IAWA list of microscopic features [34] on InsideWood [35], we saw only minimal differences. The two Tieghemella species have vessel-ray pits with distinct borders compared to $A$. congolensis and B. toxisperma. The latter two species have vessel-ray pits of two distinct sizes. The Tieghemella species both have gums and other deposits in their heartwood cells. The fibers of $A$. congolensis are very thick-walled, whereas they can be thin or thick for the other species. Autranella congolensis also has prismatic crystals present, which can be in chambered axial parenchyma cells. Finally, A. congolensis and $B$. toxisperma have a higher wood density compared to the Tieghemella spp. When comparing this description with the anatomical slices used in this study, we noticed 
Table 2 Assignment of blind test spectra used to validate the DAPC model

\begin{tabular}{llll}
\hline Test samples & Sample ID & $\begin{array}{l}\text { Class } \\
\text { probability } \\
(\%)\end{array}$ & Assigned class \\
\hline A. congolensis & Tw1765 & 75.19 & A. congolensis \\
A. congolensis & Tw5190 & 91.73 & A. congolensis \\
B. toxisperma & WFID-CBG0030 & 99.97 & B. toxisperma \\
B. toxisperma & WFID-YRNG838 & 100 & B. toxisperma \\
B. toxisperma & WFID-GRGY281 & 100 & B. toxisperma \\
T. africana & Tw22610 & 99.88 & Tieghemella spp. \\
T. heckelii & Tw26511 & 99.95 & Tieghemella spp. \\
T. heckelii & Tw64631 & 98.25 & Tieghemella spp. \\
\hline
\end{tabular}

some important differences. The specimens of $A$. congolensis and B. toxisperma also have vessel-ray pits with distinct borders. Moreover, it is not clear whether these species have vessel-ray pits of two distinct sizes. As such, this characteristic could easily be misinterpreted. All four species appear to have deposits of different proportions in their heartwood cells (mainly in ray and parenchyma cells). Our samples confirm the thick-walled fibers for $A$. congolensis, however this also appears to be the case for B. toxisperma. In our samples, the Tieghemella species have thin-to-thick walled fibers. Only Tw633 (Autranella congolensis) appeared to have prismatic crystals clearly present. As indicated by Normand (1998) [31], the fiber lumen fraction measurements might then be the only discerning characteristic for these species.

For the fiber lumen fraction measurements, all MannWhitney $\mathrm{U}$ comparisons and differences in distributions (Kolmogorov-Smirnov) were highly significant $(p<0.001)$ between all species. Based on visual assessment of the boxplots for the fiber lumen fraction measurements, $A$. congolensis and B. toxisperma tend to have a lower fiber lumen fraction than T. africana and T. heckelii. We consider this may be a valuable diagnostic characteristic for differentiating $A$. congolensis and $B$. toxisperma from the two Tieghemella species. However, when permutating the data per sample, for $A$. congolensis and B. toxisperma, $74 \%$ of the permutations were significant based on the independent 2-group Mann-Whitney $\mathrm{U}$ test. For T. africana and T. heckelii this was $80 \%$ of the permutations. This implies that even when the samples are randomly distributed across species (within either $A$. congolensis/B. toxisperma or T. heckelii/T. africana), significant differences in fiber lumen fraction are still possible. The differences in fiber lumen fraction are nuanced, implying that fiber lumen fraction is not a consistent diagnostic characteristic for the differentiation of these four species, especially when insufficient material is present to study a representative fragment of the specimen.

\section{DART-TOFMS analysis}

The PCA plot containing all ions from the four species (Fig. 4) showed that $A$. congolensis and B. toxisperma formed distinct clusters, while $T$. africana and $T$. heckelii grouped together in a third cluster. The DAPC model with the Tieghemella spp. making up a single class (Fig. 5) resulted in a LOOCV value of $96.61 \%$ and all test samples $(n=8)$ were correctly assigned, indicating that the three groups have chemotypes that were distinct enough to allow separation. Analysis of T. heckelii and T. africana showed that these two species have remarkably similar chemotypes. This could be (1) due to misidentifications that occurred during field collection, (2) because the two species are closely related, or (3) because the two species are conspecific. The first hypothesis can only be true for Tieghemella samples collected in Côte d'Ivoire, since this is the only country where the occurrence of both species has been reported [24]. However, the reports of T. africana in Côte d'Ivoire are possible erroneous because they would indicate that the species' distribution is discontinuous, since the main distribution is in Central Africa. We suspect that the T. africana individuals reported in Côte d'Ivoire are misidentified T. heckelii individuals, since both species look very similar morphologically. Our dataset included two T. heckelii samples (Tw22612 and Tw26511) collected in Côte d'Ivoire which were grouped in the PCA and correctly classified in the DAPC model with a LOOCV of $84.62 \%$ (Figure not shown). However, the LOOCV is likely increased due to the presence of

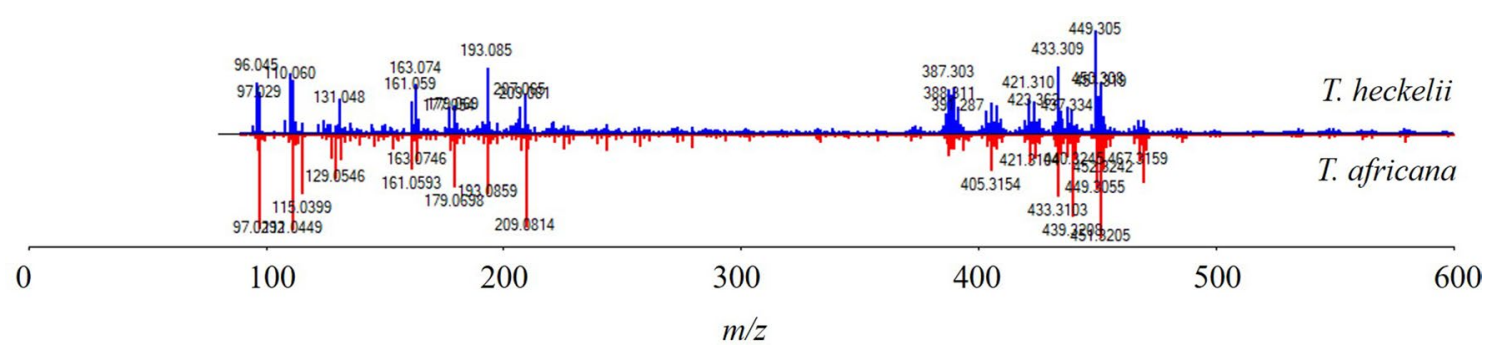

Fig. 6 Comparison spectrum of T. heckelii and T. africana shows the similarities between the two species'spectra 
replicate spectra and because of the limited sample size we could not draw definitive conclusions.

While there were many similar ions between all species analyzed in this study, the ions found in both $T$. heckelii and T. africana at $434.316,440.326$ and $452.310 \mathrm{~m} / z$ were either missing in A. congolensis and B. toxisperma spectra or relatively low in intensity, allowing for the Tieghemella species to be differentiable from $A$. congolensis and B. toxisperma with a DAPC model accuracy of $96.61 \%$. While the PCA provides some support for the hypothesis that $T$. africana and T. heckelii are more closely related than previously considered, no definitive conclusion can be drawn without a larger number of samples from the respective species. Furthermore, previous research has shown that separating species within a single family yielded a model accuracy of $82.2 \%$ [10]; this lower accuracy for closely related Meliacaeae species (due to similarity in chemotype) in conjunction with those reported for the Tieghemella spp. could indicate that the two Tieghemella species are, in fact, separate species but the genes that produced their chemotypes may be under selection. Future research should focus on obtaining both vouchered and field collected samples of the two species of Tieghemella. We hope that other researchers can add to these datasets, in the spirit of a contribution to shared knowledge, so that we can revisit the current conclusions. As was previously indicated, a taxonomic study utilizing molecular genetics would be beneficial to assess the status of the Tieghemella genus and its species limits [25, 26], as our results suggest the two species could be conspecific. This would have important implications towards the timber trade, and timber species identification.

\section{Conclusion}

In this study we assessed the wood anatomical characteristic fiber lumen fraction and DART-TOFMS analysis for species differentiation of Autranella congolensis, Baillonella toxisperma, Tieghemella africana and Tieghemella heckelii. Based on visual assessment of the boxplots for the fiber lumen fraction measurements, two groups could be discerned: (1) A. congolensis and B. toxisperma and (2) T. africana and T. heckelii. In addition, all MannWhitney $U$ comparisons and differences in distributions (Kolmogorov-Smirnov) for the fiber lumen fraction measurements were significant. When permutating our data within those two groups, significant differences based on the Mann-Whitney U test were found in $74 \%$ or $80 \%$ of the cases, respectively. This indicates that the fiber lumen fraction is not a consistent diagnostic characteristic for the identification of these four species. The chemotypes detected via DART-TOFMS of $A$. congolensis and $B$. toxisperma were distinct from each other and from those of Tieghemella spp., demonstrating that they can be identified by their chemotypes. Conversely, Tieghemella heckelii and T. africana have remarkably similar chemotypes that hinder species identification, and further taxonomic research is needed to assess whether they could be conspecific. Our study shows that chemical profiling can be used to reliably distinguish $A$. congolensis, B. toxisperma and Tieghemella spp. However, without additional vouchered specimens of the Tieghemella spp., we are limited in our ability to distinguish Tieghemella africana from Tieghemella heckelii. In conclusion, distinguishing the timber of the Tieghemella species is difficult, as the fiber lumen measurements are too similar and the specimens required for chemical analysis were scarce. The ability to definitively separate closely related members from taxonomically challenging groups, such as Sapotaceae, is often required by law enforcement agencies. As such, future research will concentrate on obtaining vouchered Tieghemella africana and Tieghemella heckelii samples in an effort to verify if a method can be established to separate these species.

\section{Supplementary Information}

The online version contains supplementary material available at https://doi. org/10.1186/s13007-021-00766-x.

Additional file 1: Fig S1. Macroscopic scan of the heartwood for $A$ congolensis, B. toxisperma, T. africana and T. heckelii.

Additional file 2: Table S1. Sample information showing the species, object ID (Tw = Tervuren Wood Collection, Belgium and World Forest ID collection at Kew = Royal Botanic Gardens Kew, United Kingdom), Country of Origin (UNK = unknown) and whether the sample was used for the wood anatomical analysis or DART TOFMS analysis. The green samples also have a corresponding herbarium voucher at Meise Botanic Garden (BR) in Belgium.

Additional file 3: Fig S2. Plot showing the number of PC's and Cumulative Variance (\%) for the PCA.

Additional file 4: Fig S3 PCA scatterplot for T. heckelii and T. africana using replicates from all T. heckelii $(n=16)$ and T. africana $(n=10)$ samples.

\section{Acknowledgements}

The authors would like to thank the Royal Museum for Central Africa (Tervuren, Belgium) and World Forest ID (https://worldforestid.org/) for the management and planning of the sample collection. The findings and conclusions in the article are those of the authors and do not necessarily represent the views of the U.S. Fish and Wildlife Service or of the U.S. Forest Service.

\section{Authors' contributions}

$\mathrm{HB}$ and VD conceptualized the study design. $\mathrm{KL}$ and $\mathrm{HB}$ prepared the wood anatomical slices and $K L$ and VD performed the wood anatomical analysis. EP and EE performed the DART-TOFMS analysis and interpreted the DART-TOFMS data. VD, EP and SVA were the major contributors in writing the manuscript. SVA was also major contributor in revising the manuscript and was also responsible for the taxonomic and genetic input for this study. All authors read and approved the final manuscript.

\section{Funding}

This research was conducted under the HERBAXYLAREDD project, funded by the Belgian Belspo-BRAIN program axis 4 (code: BR/143/A3/HERBAXYLAREDD). BELSPO provided the main funding and support for this study. SVA was 
supported individually by a Postdoctoral Fellowship of the Belgian American Educational Foundation (www.baef.be).

\section{Availability of data and materials}

The datasets used and/or analyzed during the current study are available from the corresponding author on reasonable request.

\section{Declarations}

Ethics approval and consent to participate

Not applicable.

\section{Consent for publication}

Not applicable.

\section{Competing interests}

The authors declare that they have no competing interests. The findings and conclusions in the article are those of the authors and do not necessarily represent the views of the U.S. Fish and Wildlife Service or of the U.S. Forest Service.

\section{Author details}

${ }^{1}$ Service of Wood Biology, Royal Museum for Central Africa (RMCA), Leuvensesteensweg 13, 3080 Tervuren, Belgium. ${ }^{2}$ Royal Botanic Gardens Kew, Richmond, Surrey TW9 3AE, United Kingdom. ${ }^{3}$ U.S. Forest Service International Programs Wood Identification \& Screening Center, Richardson Hall 109, 3180 SW Jefferson Way, Corvallis, OR 97331, USA. ${ }^{4}$ U.S. Fish and Wildlife Forensic Laboratory, 1490 East Main Street, Ashland, OR 97520, USA. ${ }^{5}$ School of Integrative Plant Science, Section of Plant Biology and the L.H.Bailey Hortorium, Cornell University, Ithaca, NY, USA.

Received: 13 February 2021 Accepted: 10 June 2021

Published online: 22 June 2021

\section{References}

1. Hirschberger P. Illegal wood for the European market. An analysis of the EU import and export of illegal wood and related products. (N. Griesshammer \& A. Schulmeister, Eds.). Frankfurt am Main. 2008.

2. Hoare A. Tackling Illegal Logging and the Related Trade. What progress and Where Next? The Royal Institute of International Affairs, Chatham House, London, England, UK. 2015. https://www.chathamhouse.org/ 2015/07/tackling-illegal-logging-and-related-trade-what-progress-andwhere-next. Accessed 8 July 2020.

3. INTERPOL, World Bank. CHAINSAW PROJECT An Interpol perspective on law enforcement in illegal logging. Lyon. 2006. https://interpol.int. Accessed 8 July 2020.

4. Lowe AJ, Dormontt EE, Bowie MJ, Degen B, Gardner S, Thomas D, Clarke C, Rimbawanto A, Wiedenhoeft A, Yin Y, Sasaki N. Opportunities for improved transparency in the timber trade through scientific verification. BioScience. 2016. https://doi.org/10.1093/biosci/biw129.

5. Nellemann C, INTERPOL Environmental Crime Programme. Green Carbon, Black Trade: Illegal Logging, Tax Fraud and Laundering in the Worlds Tropical Forests. A Rapid Response Assessment. United Nations Environment Programma. GRID-Arendal, Norway. 2012. http://www.grida.no/ publications/rr/green-carbon-black-trade/. Accessed 8 July 2020.

6. Vlam M, de Groot GA, Boom A, Copini P, Laros I, Veldhuijzen K, Zakamdi D, Zuidema PA. Developing forensic tools for an African timber: Regional origin is revealed by genetic characteristics, but not by isotopic signature. Biol Conserv. 2018;220:262-71. https://doi.org/10.1016/j.biocon.2018.01. 031.

7. Rosa da Silva N, De Ridder M, Baetens JM, Vanden Bulcke J, Rousseau M, Martinez Bruno O, Beeckman H, Van Acker J, De Baets B. Automated classification of wood transverse cross-section micro-imagery from 77 commercial Central-African timber species. Ann For Sci. 2017. https://doi. org/10.1007/s13595-017-0619-0.

8. Beeckman H. Wood anatomy and trait-based ecology. IAWA J. 2016;37(2):127-51. https://doi.org/10.1163/22941932-20160127.
9. Gasson P, Baas P, Wheeler E. Wood anatomy of CITES-listed tree species. IAWA J. 2011;32(2):155-98.

10. Deklerck V, Mortier T, Goeders N, Cody RB, Waegeman W, Espinoza E, Van Acker J, Van den Bulcke J, Beeckman H. A protocol for automated timber species identification using metabolome profiling. Wood Sci Technol. 2019;53:953-65. https://doi.org/10.1007/s00226-019-01111-1.

11. McClure PJ, Chavarria GD, Espinoza E. Metabolic chemotypes of CITES protected Dalbergia timbers from Africa, Madagascar, and Asia. Rapid Commun Mass Sp. 2015:29(9):783-8. https://doi.org/10.1002/rcm.7163.

12. Lancaster C, Espinoza E. Analysis of select Dalbergia and trade timber using direct analysis in real time and time-of-flight mass spectrometry for CITES enforcement. Rapid Commun Mass Sp. 2012;26(9):1147-56. https:// doi.org/10.1002/rcm.6215.

13. Jolivet C, Degen B. Use of DNA fingerprints to control the origin of sapelli timber (Entandrophragma cylindricum) at the forest concession level in Cameroon. Forensic Sci Int-Gen. 2012;6(4):487-93. https://doi.org/10. 1016/j.fsigen.2011.11.002.

14. Paredes-Villanueva K, Espinoza E, Ottenburghs J, Sterken MG, Bongers F, Zuidema PA. Chemical differentiation of Bolivian Cedrela species as a tool to trace illegal timber trade. Forestry. 2018;91(5):603-13. https://doi.org/ 10.1093/forestry/cpy019.

15. Bickford D, Lohman DJ, Sodhi NS, Ng PKL, Meier R, Winker K, Ingram KK, Das I. Cryptic species as a window on diversity and conservation. Trends Ecol Evol. 2007;22:148-55. https://doi.org/10.1016/j.tree.2006.11.004.

16. Daïnou K, Blanc-jolivet C, Degen B, Kimani P, Ndiade-bourobou D, Donkpegan ASL, Tosso F, Kaymak E, Bourland N, Doucet J, Hardy OJ. Revealing hidden species diversity in closely related species using nuclear SNPs, SSRs and DNA sequences - a case study in the tree genus Milicia. BMC Evol Biol. 2016;16:259. https://doi.org/10.1186/s12862-016-0831-9.

17. Duminil J, Kenfack D, Viscosi V, Grumiau L, Hardy OJ. Testing species delimitation in sympatric species complexes: the case of an African tropical tree, Carapa spp (Meliaceae). Mol Phylogenet Evol. 2012;62:275-85. https://doi.org/10.1016/j.ympev.2011.09.020.

18. Naciri Y, Linder HP. Species delimitation and relationships: the dance of the seven veils. Taxon. 2015;64(1):3-16. https://doi.org/10.12705/641.24

19. Stegemann S, Keuthe M, Greiner S, Bock R. Horizontal transfer of chloroplast genomes between plant species. PNAS. 2011;109(7):2434-8.

20. Maddison WP. Gene trees in species trees. Syst Biol. 1997:46(3):523-36.

21. Swenson U, Anderberg A. Phylogeny, character evolution, and classification of Sapotaceae (Ericales). Cladistics. 2005;21:101-30.

22. Pennington TD. The Genera of Sapotaceae. Royal Botanic Gardens, Kew \& New York Botanical Garden.. 1991. Pp. 124-127 (Autranella, Tieghemella, Baillonella)

23. Govaerts R, Frodin DG, Pennington TD. World checklist and bibliography of Sapotaceae. Kew: Royal Botanic Gardens; 2001.

24. Dahms KG. Afrikanische Exporthölzer. 3 Auflage. DRW Verlag LeinfeldenEchterdingen. 1999. Pp. 358

25. Lemmens RHMJ. Tieghemella africana Pierre. In: Louppe, D., Oteng-Amoako, A.A. \& Brink, M. (Editors). PROTA (Plant Resources of Tropical Africa / Ressources végétales de l'Afrique tropicale), Wageningen, Netherlands. 2005. https://uses.plantnet-project.org/en/Tieghemella_africana_(PROTA) Accessed 23 Sep 2019.

26. Bonnéhin L, Lemmens RHMJ. Tieghemella heckelii (A.Chev.) Roberty. In: Louppe, D., Oteng-Amoako, A.A. \& Brink, M. (Editors). PROTA (Plant Resources of Tropical Africa / Ressources végétales de l'Afrique tropicale), Wageningen, Netherlands. 2005. https://uses.plantnet-project.org/en/ Tieghemella_heckelii_(PROTA). Accessed 23 Sep 2019.

27. Lemmens RHMJ. Autranella congolensis (De Wild.) A.Chev. In: Louppe, D., Oteng-Amoako, A.A. \& Brink, M. (Editors). PROTA (Plant Resources of Tropical Africa / Ressources végétales de l'Afrique tropicale), Wageningen, Netherlands. 2007. https://uses.plantnet-project.org/en/Autranella congolensis (PROTA). Accessed 23 September 2019.

28. Louppe D. Baillonella toxisperma Pierre. In : Louppe, D., Oteng-Amoako, A.A. \& Brink, M. (Editors). PROTA (Plant Resources of Tropical Africa / Ressources végétales de l'Afrique tropicale), Wageningen, Netherlands. 2005. https://uses.plantnet-project.org/en/Baillonella_toxisperma_(PROTA). Accessed 23 Sep 2019.

29. Pierre L. Notes botaniques: Sapotacees. Paris. 1890.

30. Musée colonial de Marseille. Annales du Muśee colonial de Marseille. Marseille: Faculté des sciences de Marseille, Musée colonial; 1915. 
31. Normand D. Manuel d'identification des bois commerciaux - Tome 1: Généralités. Centre Technique Forestier Tropical, 45 bis, Av. de la BelleGabrielle, 94-Nogent s/Marne 1972. 1998.

32. Normand D, Paquis J. Manuel d'identification des bois commerciaux Tome 2: Afrique guinéo-congolaise. Centre Technique Forestier Tropical, 45 bis, Av. de la Belle-Gabrielle, 94-Nogent s/Marne 1972. 1976.

33. Gasson P, Lancaster CA, Young R, Redstone S, Miles-Bunch IA, Rees G, Guillery RP, Parker-Forney M, Lebow ET. WordForestID: addressing the need for standardized wood reference collections to support authentication analysis techhnologies; a way forward to checking the origin and identity of traded timber. Plants People Planet. 2020;3:1-12.

34. Wheeler EA, Baas P, Gasson PE. IAWA list of microscopic features. IAWA Bull. 1989;10(3):219-332.

35. Wheeler EA. InsideWood - A Web resource for hardwood anatomy. lawa J. 2011;32(2):199-211

36. Wickhamn H, Chang W. Package ggplot2, Create Elegant Data Visualisations using the Grammer of Graphics. 2016. Pp. 189
37. Shapiro SS, Wilk MB. An analysis of variance test for normality (complete samples). Biometrika. 1965;52(3-4):591-611.

38. Mann HB, Whitney DR. On a test of whether one of two random variables is stochastically larger than the other. Ann Math Stat. 1947;18:50-60.

39. Jombart T, Devillard S, Balloux F. Discriminant analysis of principal components: a new method for the analysis of genetically structured populations. BMC Genet. 2010;11(1):94. https://doi.org/10.1186/ 1471-2156-11-94

40. Price E, Larrabure D, González BA, Espinoza E. Forensic identification of the keratin fibers of South American camelids by ambient ionization mass spectrometry: Vicuña, alpaca and guanaco. Rapid Commun Mass Sp. 2020;34(23):1-9. https://doi.org/10.1002/rcm.8916.

\section{Publisher's Note}

Springer Nature remains neutral with regard to jurisdictional claims in published maps and institutional affiliations.
Ready to submit your research? Choose BMC and benefit from:

- fast, convenient online submission

- thorough peer review by experienced researchers in your field

- rapid publication on acceptance

- support for research data, including large and complex data types

- gold Open Access which fosters wider collaboration and increased citations

- maximum visibility for your research: over $100 \mathrm{M}$ website views per year

At BMC, research is always in progress.

Learn more biomedcentral.com/submissions 